\title{
Geotechnical and ecological foundations of the sustainable life cycle of the long-operated unique underground structures of the water disposal system in difficult ground conditions
}

\author{
Nicolay Perminov ${ }^{1, *}$ \\ ${ }^{1}$ Emperor Alexander I State Transport University, 9 Moskovsky Pr., St. Petersburg, 190031, Russia
}

\begin{abstract}
Intensive development of megacities causes the need for sustainable operation of underground urban infrastructure facilities. In the special protection against man-made impact, long-operated unique underground structures of the water disposal system, which are related to facilities with an increased level of responsibility and danger, are needed. In the report, based on the experience of studying the operation of underground wastewater facilities in conditions of weak soils and intensive external static and dynamic impacts, there are proposed new methods for diagnosing their technical condition, modeling and monitoring of the joint work of the "underground structures - aggregate of soil" system are implemented, forecasting and shaping conditions for its sustainable life cycle. Point and linear objects of the water canal of St. Petersburg are developed and implemented at unique (to a depth of $70 \mathrm{~m}$.) geotechnology, providing simultaneous increase of bearing capacity, operational reliability and ecological safety of long- operated underground drainage facilities in difficult ground conditions with increasing man-caused impacts.
\end{abstract}

\section{Introduction}

General information about the object of deep engineering infrastructure in large cities. With long-term operation and intensive development of engineering infrastructure of megalopolises increase the requirements to the ecology and efficient usage of land resources. During engineering development of underground spaces of such a megalopolis, design of integrated measures for protection of town-planning environment against negative anthropogenic impact is of special actuality. Thereupon there must be introduced special safety requirements for the sewage and water treatment facilities. Sewage (transportation) of waste waters is done through the city sewerage system and tunnel collectors. In the general drainage system these facilities account for up to $60 \%$ in large cities and up to $70 \%$ in difficult hydrogeological conditions by construction volumes and costs.

Sewerage system objects data for the most typical Russian cities with the population over 1 million people is given in table 1 .

\footnotetext{
* Corresponding author: perminov-n@mail.ru
} 
Table 1. Length of sewerage networks and tunnel collectors in large cities of Russian Federation.

\begin{tabular}{|l|c|c|}
\hline \multicolumn{1}{|c|}{ City } & Sewerage networks length, $\mathrm{km}$ & Tunnel collectors length, $\mathrm{km}$ \\
\hline Moscow & 8354 & 550 \\
\hline St. Petersburg & 8245 & 290 \\
\hline Volgograd & 1054 & 52 \\
\hline Yekaterinburg & 1220 & 230 \\
\hline Novosibirsk & 1150 & 145 \\
\hline Samara & 1200 & 215 \\
\hline Ufa & 900 & 180 \\
\hline
\end{tabular}

By now around $88 \%$ of all sewage collectors are made of ferroconcrete, around $7 \%$ - of metal (steel, cast iron), around 3\% - of bricks, plastic, ceramics. Tunnel sewage collectors diameter is from 1.2 to $5.6 \mathrm{~m}$, they are buried from 3 to $60 \mathrm{~m}$ underground. For example, in St. Petersburg all sewage network is divided into three basins that serve three main pumping plants up to $70 \mathrm{~m}$ deep and up to $66 \mathrm{~m}$ in diameter, with productivity of $1.5 \mathrm{mln} \mathrm{m} 3$ of sewage per day. For such conditions the main constructive solution for the tunnels are the ferroconcrete tubings with inner ferroconcrete jackets.

Transportation volumes of waste waters in some sections of the tunnels reach $20 \mathrm{~m} 3$ per sec, and in case of decrease of their operational reliability or failure will inevitably lead to a technospheric catastrophe. "Lengiproinzhproekt" institute together with the St. Petersburg State Transportation University has been providing scientific and engineering maintenance, design, construction and rehabilitation of St. Petersburg sewerage system objects for more than 30 years: more than 70 pumping plants, including those with depth of $45 \mathrm{~m}, 59 \mathrm{~m}$ and $71 \mathrm{~m}$, and with diameters of $47 \mathrm{~m}, 59 \mathrm{~m}$ and $66 \mathrm{~m}$; more than $15 \mathrm{~km}$ of tunnel sewage collectors with diameters of 1.85, 2.5 and $3.4 \mathrm{~m}$ and with depth of $16 \mathrm{~m}, 24$ and $37 \mathrm{~m} \mathrm{[1].}$

Table 2 shows the most typical defects of long-term operated pumping plants and deep tunnels.

Table 2. The list of defects typical for the long-term operated (more than 30-45 years) deep pumping plants and tunnel collectors.

\begin{tabular}{|c|c|c|c|}
\hline \multirow{2}{*}{$\begin{array}{l}\begin{array}{l}\text { Location } \\
\text { of the } \\
\text { defect }\end{array} \\
\text { Sunk } \\
\text { wells } \\
\text { walls }\end{array}$} & \multicolumn{3}{|c|}{ Description and photo of the defect } \\
\hline & $\begin{array}{l}\text { Up to }-25 \div 30 \mathrm{~m} \text { marks. } \\
\text { On some sections of sunk } \\
\text { well walls there's leakage } \\
\text { through knots. In the knots } \\
\text { area there's leakage of } \\
\text { concrete corrosion. } \\
\text { Defects are of repetitive } \\
\text { nature. }\end{array}$ & $\begin{array}{l}-30 \text { to }-40 \div 45 \mathrm{~m} \text { marks. } \\
\text { On the surface of the } \\
\text { wall there're marks of } \\
\text { intense leakage through } \\
\text { the cracks. Defects are } \\
\text { of mass nature. In the } \\
\text { knots area there's } \\
\text { leakage of concrete } \\
\text { corrosion. }\end{array}$ & $\begin{array}{l}\text { More than }-45 \mathrm{~m} \text { marks. } \\
\text { On the surface of the } \\
\text { wall there're marks of } \\
\text { intense leakage through } \\
\text { the cracks. In the knots } \\
\text { area there's leakage of } \\
\text { concrete corrosion. } \\
\text { Defects are of mass } \\
\text { nature. }\end{array}$ \\
\hline $\begin{array}{l}\text { Sewage } \\
\text { tunnels } \\
\text { lining }\end{array}$ & $\begin{array}{l}\text { Tubing lining shows } \\
\text { leakage. Underground } \\
\text { waters go to the collector } \\
\text { through cracks and knots } \\
\text { in solid ferroconcrete } \\
\text { inside lining. There's } \\
\text { leakage of concrete } \\
\text { corrosion and salts. }\end{array}$ & $\begin{array}{l}\text { There's a water-filled } \\
\text { space in the form of a } \\
\text { thin gap between the } \\
\text { tubing lining and the } \\
\text { jacket of collector. } \\
\text { Defects are hidden, can } \\
\text { be found geological } \\
\text { radar probing of } \\
\text { collector facilities. }\end{array}$ & $\begin{array}{l}\text { Solid ferroconcrete inner } \\
\text { lining (jacket) is } \\
\text { destroyed, there's } \\
\text { intense leakage in } \\
\text { welded seams. }\end{array}$ \\
\hline
\end{tabular}

Analysis of the materials of the investigations shows that at the moment $60 \%$ of gravity sewage tunnels and $80 \%$ of pressure sewage tunnels require repairs and sanitation. 
Instrumental probing (with geological radar) shows that $70-75 \%$ of inner surface of pumping plants wells and sewage tunnels have continuity violation and cracks which require strengthening of construct and renewal of waterproof shell.

\section{Analysis of factors influencing the safety of deep engineering structures and measures for their elimination}

\subsection{Analysis of monitoring data for the construction of sunk large pumping plants and of the inspection results after long term operation}

The slotted soil column for construction of sunk wells for main pumping plants in the conditions of St. Petersburg is characterized as follows: top part is presented by quaternary beddings to the depth of 14.0-25.0 meters (middle-density water-saturated dust sand $\mathrm{E}=11$ $\mathrm{MPa}, \mathrm{C}=0 \mathrm{MPa}, \varphi=30^{\circ}$; laminar silt sandy loam $\mathrm{E}=4 \mathrm{MPa}, \mathrm{C}=0.01 \mathrm{MPa}, \varphi=15^{\circ}$; laminar silt loam, very soft $\mathrm{E}=9 \mathrm{MPa}, \mathrm{C}=0.025 \mathrm{MPa}, \varphi=16$; semisolid silt loam with gravel, pebbles $\left.\mathrm{E}=14 \mathrm{MPa}, \mathrm{C}=0.028 \mathrm{MPa}, \varphi=28^{\circ}\right)$, lower part is represented by top of positioned Proterozoic bluestone $\left(\mathrm{E}=19 \mathrm{MPa}, \mathrm{C}=0.04 \div 0.06 \mathrm{MPa}, \varphi=18-21^{\circ}\right)$.

The stresses in the reinforcement and concrete were measured using primary device string type PSAS and PLDS. To determine the soil pressure membrane load cells with a range of 0 to $12 \mathrm{MPa}$ and measurement error of $5-7 \%$ were used. The measurement was done both in the discrete and continuous mode using the local electronic switches (LEC), and data storages (END).

Analysis of monitoring data of large sunk wells with diameters from 50 to $66 \mathrm{~m}$ and a depth of immersion of 55 to $71 \mathrm{~m}$ shows that in the process of immersion in the soils with different strengths and asymmetric structures deviation from the vertical axis (careen) is observed, with a shift of the center up to 1.5-1.8 $\mathrm{m}$. In this case, according to an automated continuous monitoring, as a result of abrupt landings (breakdowns) stresses in the reinforcement, concrete and soil pressure may exceed the calculated and the average values (according to the discrete measurements) 12-15 times.

To estimate the stress-strain state of the well shell with a sharp landing (breakdown) numerical modeling was conducted. In the calculations the finite element method (FEM) and the software package Robot Professional 2010 were used. The calculation is carried out for spatial shell with diameter of $66 \mathrm{~m}$ and a height of $71 \mathrm{~m}$ (with the number of three-dimensional finite elements equal 50828), falling under its own weight at an angle of $15^{\circ}$ from a height of $140 \mathrm{~cm}$ on the compliant soil (average coefficient of elasticity for multilayer soil is taken $\mathrm{K}=16500 \mathrm{kN} / \mathrm{m} 3)$. In the model because of the inclination angle the friction forces on the lateral side of the well were applied in the upper part of the shell on one side and in the bottom part on the opposite side [3].

The results of numerical modeling have shown (see Fig. 1) that in case of a dynamic blow (if the well is dropped from a height of $140 \mathrm{~cm}$ ) equivalent von Mises stresses in the construct equal $\mathrm{Sdin}=256 \mathrm{MPa}$ at the top of the shell and $\mathrm{Sdin}=1538 \mathrm{MPa}$ in the area of the bottom rest, which respectively exceeds the limiting strength of concrete class B30 [Spred] to 14 or more times, and the changes in the geometry of the shell are observed. 
a)

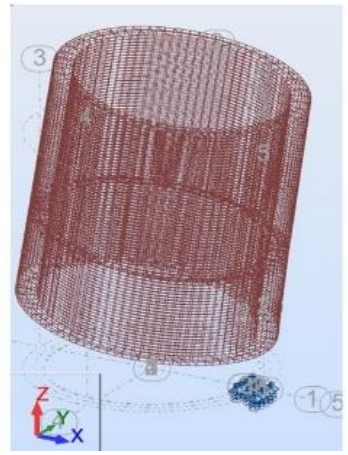

b)

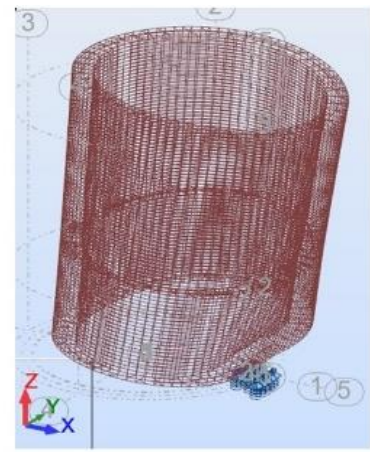

Fig. 1. The results of numerical modeling of a sunk well with diameter of $66 \mathrm{~m}$ and a height of $71 \mathrm{~m}$ for the conditions of a abrupt landing (breakdown): a) the original position, and b) position after a fall from a height of $1.4 \mathrm{~m}$ at an angle of $15^{\circ}$.

Thus, already in the process of the well immersion the construction of the well is damaged and the concrete is disintegrated due to breakdowns. Later during operation micro cracks lead to leakage, seepage and corrosion of concrete. To further ensure the safety of operation of facilities of this type it is necessary to strengthen and waterproof the construct by highpressure injection of polymer resins [4].

\subsection{Geotechnical analysis of technical condition of the sewage tunnels under intensive anthropogenic impact and long term operation}

Geotechnical analysis of the sewage tunnel was carried out for the most typical section located in a zone of intense dynamic impact of transport and the impact of new construction. Figure 2 shows the diagram of the tunnel compressions for more than 35 years of service life.

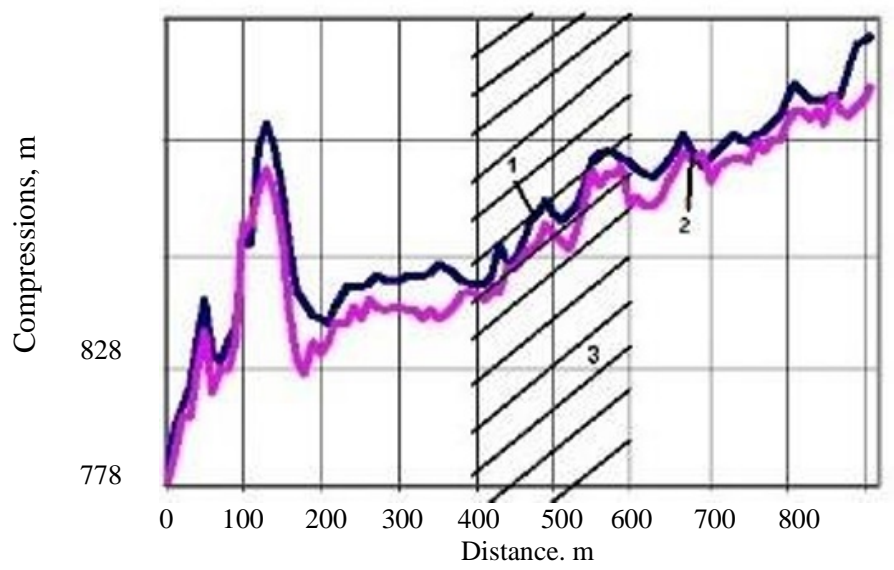

Fig. 2. The diagram of comparison of the compressions on the arch axis of the collector: the diagram of compressions: 1 - survey results of 2010, 2 - executive survey data of 1975, 3-area of the collector, protected from the influence of the construction be a screen of low modular material.

Uneven tunnel compressions, modified on the arch axis range from 5 to $276 \mathrm{~mm}$. Comparative analysis of engineering and geological section on the tunnel route and its placement on the plan relative to the traffic junction showed that the greatest compressions up to $276 \mathrm{~mm}$ are located in the area of the tunnel under intense dynamic effects of the traffic, passing the layer of thixotropic quaternary deposits. Evaluation of the dynamic impact of the 
transport was carried out by the study of the oscillatory process with a set of manifold gauges CM TSP installed in the arch and blocks of the recording equipment [5].

The frequency of the oscillations of the collector during various traffic loads from 15 to $35 \mathrm{~Hz}$, and the vibration amplitude to 35-70 microns was recorded. According to the research [6] for this type of ground deposits and the appropriate level of the dynamic effects the decrease of strength characteristics $\mathrm{C}$ and $\varphi$ is up to $35 \%$ and $17 \%$, respectively. To ensure the operational reliability of tunnels vibration protection measures, such as the use of spiralwound technology for internal lining the tunnel are suggested.

a)
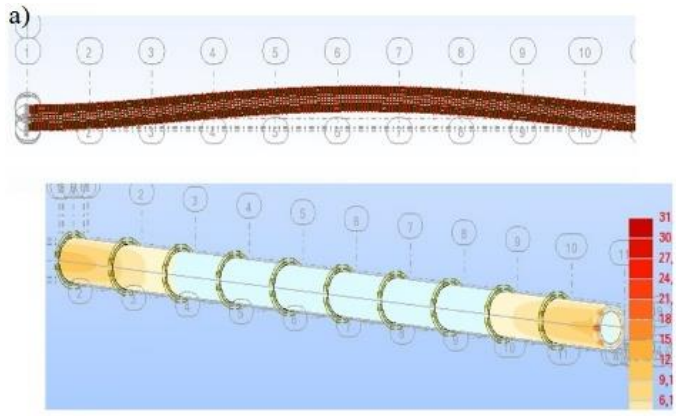

b)

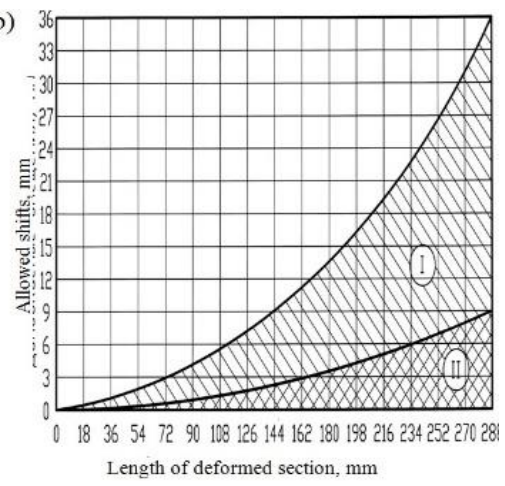

Fig. 3. Calculated model of the tunnel (a), the diagram of maximum allowable tunnel lining deformation (b): 1 - Safe displacement values after the lining has been strengthened, 2 - reference value of allowed displacement.

For this section of the collector the numerical modeling was carried out to determine the maximum allowable axis displacement of tunnel lining. The criterion for the safety of the construct is the maximum allowable tensile stress of the concrete in the typical points of lining. Maximum allowable deformation and displacement values are presented in Figure 3.

\section{Conclusion}

Data received from long-term field observations for continuous operated embedded constructions being a part of megapolis water discharge system as well as the results of calculation and modeling allowed to conduct geotechnical analysis of the residual bearing capacity and to develop measures to ensure the safe operation of facilities of such type under the conditions of intensive external influences.

As experience shows, the presence of geotechnical tracking of environmentally hazardous facilities of such type for the entire period of their life cycle, including design, construction and long-term operation (even under intensive man-induced impact) provides the safety of the stable functioning of the megapolis utility infrastructure.

The carried out researches are a basis for geotechnical maintenance of steady functioning and ecological safety of underground constructions of a water removal at all stages of their life cycle.

\section{References}

1. N.A. Perminov, V.N. Zencov, A.N. Perminov, Proc. of the 13th World Conf. of ACUUS: Advances in Underground Space Development, 276-286 (2013)

2. N.A. Perminov, S.V. Lombas, Proc. of Int. Geotechnical Conf. dedicated to the Year of Russia in Kazakhstan, 344-351 (2004) 
3. M.S. Barabash, Computer simulation of the life cycle of construction projects: Monograph (Publishing House Steel, 2014)

4. J. Ameratunga, D. Brown, R. Ramachadran, R. Denny, Proceedings of the 17th ICSMGE, 2280-2283 (2009)

5. N.A Perminov, Geotechics jf Had Soils-Weak Rocks, Experience of tunnel collectors monitoring at engineering development of underground face of megapolis, Part 3 (2011)

6. M.N. Goldshtein, L.S. Lapidus, O.M. Reznikov, V.I. Storozhenko, N.I. Sinaevsky, Particularities of dynamic properties of soils with pulsating load on the surface, (Stroyizdat, Moscow, 1973) 